\title{
Галина Мишкинене
}

Институт литовского языка

\section{Славяно-турецкое языковое и культурное взаимодействие (на материале хамаилов литовских татар) ${ }^{1}$}

\section{1. Введение}

Хамаилы (молитвенники) - одна из многих разновидностей литературного наследия татар Великого княжества Литовского (далее - ВКЛ). Потомки татар ВКЛ, ныне проживающие на территории трех государств - Беларуси, Литвы и Польши, после более чем двухсотлетнего проживания в ВКЛ, к началу XVII в. в силу ряда причин утрачивают свой родной тюркский язык [Miškinienè 2011: 13-14]. Появление белорусских текстов, писанных арабским письмом в середине XVI в., а в XVII-XX вв. - и на польском, связано с историей языковой ассимиляции татар, а также с периодом Реформации, когда у входивших в состав ВКЛ народов возрос интерес к своей истории, культуре, религии. К этому периоду относится и первый перевод Корана [(Tefsir Tatarów) 2015].

Языковая ассимиляция сделала необходимым перевод на белорусский, а затем и польский языки религиозной литературы: сур Корана, непонятных литовским татарам ${ }^{2}$ арабских текстов молитв, легенд о пророке Мухаммаде. Среди многочисленных жанровых разновидностей рукописного наследия литовских татар - Коранов, тефсиров, теджвидов, китабов, полукитабов - хамаилы занимают особое место, поскольку литовские татары, у которых литургический язык не совпадает с языком разговорным, именно в них черпали основные знания по проведению религиозных обрядов, совершению одного из

1 Artykuł zostanie wygłoszony na XVI Międzynarodowym Kongresie Slawistów (Belgrad, 20-27 sierpnia 2018 roku).

2 В данной работе используется термин „литовские татары” как указание на территорию ВКЛ, куда в XIV-XVI вв. переселилась основная масса тюркоязычных мигрантов из Золотой Орды. 
обязательных условий ислама - намазов, здесь находили пояснения к молитвам и их предназначению, объяснения по мусульманской астрологии и летоисчислению. Тексты, входящие в состав хамаилов, могли подбираться с учетом заказчика или по усмотрению самого составителя/переписчика. По содержанию хамаилы можно подразделить в основном на три типа: 1) моллинские, предназначенные для имамов, содержащие в основном молитвы и трактовку обрядов, 2) фалджейские 3 , с преобладанием магических формул и астрологических таблиц, используемых фалджеями-прорицателями, 3) смешанного типа.

В данной статье славяно-турецкое языковое и культурное взаимодействие рассматривается на материале хамаилов литовских татар. Объектом исследования стали два хамаила - хамаил Сафара Кабирова (середина ХІХ в.) и хамаил ЛУ-869 (1-ой половины ХІХ в.). Как большинство рукописей литовских татар, исследуемые нами рукописи многоязычны. Помимо белорусских или польско-белорусских текстов, рукописи содержат многочисленные инклюзии на арабском и староосманском языках. Особенностью данных кодексов и их ценность заключаются в том, что большинство помещенных в них текстов переведено на вышеуказанные славянские языки. Обычно приводимые в хамаилах молитвы и обрядовые действия сопровождаются довольно коротким пояснительным текстом, за которым следует текст молитв на арабском (реже - турецком) языках без перевода. На данный момент нам известно несколько рукописей, в которых мусульманские молитвы сопровождаются линеарным переводом на белорусский и польский языки. Одной из таких рукописей является полукитаб из фондов Центральной научной библиотеки НАН Беларуси (Инв. № Р97) [Тарэлка 2011: 13-14], а также исследуемые нами хамаилы. Таким образом, указанные кодексы могут служить прекрасным материалом для сравнения некоторых переводных текстов молитв.

\section{2. Палеографические и содержательные особенности исследуемых рукописей}

Прежде чем охарактеризовать содержание исследуемых рукописей, приведем их самые необходимые палеографические характеристики, поскольку полное описание было представлено в предшествующих работах автора данной статьи (см. далее).

3 Фалджейский - от турецкого слова falc1 'предсказатель' (< apaб. fal 'гадание' + тур. аффикс '-сI', определяющий профессию). 
Рукопись, названная по имени владельца - хамаил Сафара Кабирова (далее - ХСК), хранится в Отделе рукописей и редкой книги научной библиотеки Казанского (Приволжского) федерального университета под сигнатурой 3246 ap. Рукопись можно датировать серединой XIX в. 1844 г. Первичные сведения о рукописи ХСК опубликованы в 2007 г. [Мишкинене 2007: 263-285], полное описание рукописи - в 2015 г., в статье „Арабографичные рукописи литовских татар в контексте культурных взаимосвязей: коллекции Казанского (Приволжского) федерального университета и Национальной библиотеки Республики Татарстан" [Мишкинене 2015: 49-53].

Ниже предлагаем наше деление на темы с условными названиями и приведением инципитов (в скобках отмечены страницы хамаила):

1. За кого следует читать молитвы: баб то йест порондек мусуулманскии и поввийо̄с̀ ведзеи... чтердзес̀ие кур 'ано̄в аллбо йас̀новв... (1a-2a);

2. Молитва при входе в мечеть: баб до мечеци пришовщи три кроќи стонпивщи то треба пец... (2б-3a);

3. Молитва на могиле: баб 'алей с̀венти о̄д пророка йет̄ милос̀и

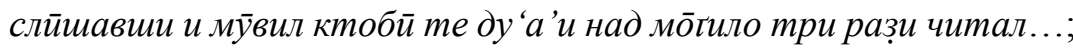
баб те ду 'а'и на мусулманс̀кей мотиле... (3а-5б);

4. Нийет к суре Йа Син: баб то йест ниййет́ до йас̀ену... (5б-11a);

5. Сура ал-Фатиха: с̀урет́ алфат́иха... (11a-12a);

6. Сура Йа Син: с̀урет́ йас̀ин...(12б-26б);

7. Сура ал-Ихлас: с̀урет́ ихлас...(26б-27a);

8. Сура ал-Фалаки: суурет́ алфалек... (27a);

9. Сура ал-Наси и ал-Фатиха: c̀yре⿱́ ал наси...; c̀ypeḿ алфат́иха... (27б);

10. Сура ал-Бакарат: с̀урет́у ал баќерет́... (28a-32a);

11. Текбир 4 до и после еды: баб то йест пред йедзеием тен т́еќбир пеи гадзидзиа ... по йедзейӯ руики по̄днавщи тетй т́еќбир гожо̄ пец... (326-33a);

12. Молитва перед посещением больного: баб дорхоррето идо̄ни наведзец то по̄треба пец... (33б);

13. Молитвы во время похоронного обряда: баб то̄ маш ведзеи йаким по̄ро̄нд о̄ко̄ло̄ меййит́ ру упии... (34a-56a);

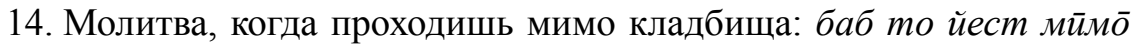
мизаруу идо̄u то та ду 'а' 'и треба пец... (56a-57a);

4 Такбир - произнесение формулы „Аллаху акбар” (Аллах велик). 
15. Молитва во время абдеса': баб хто хие кур 'ан хет́йм пец̧ за дуиша чийа найпро̄ḿ по̄ḿреба вз́о̄ни абдес̀m... (57a-64б);

16. Гусл ${ }^{6}$ : баб той ест до̄ гус́лу по̄ро̄ндек... (64б-68а);

17. Порядок совершения намаза: баб поро̄ндек до̄ немаз́у каждй мус́улманин и мус́улманка повийй ведзец йак веле ве немаз́е ктуурим реќ 'ато̄в... (68a-68б);

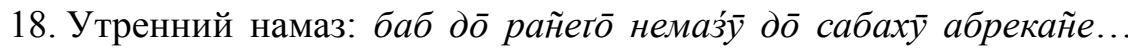
(686-74a);

19. Салават ${ }^{7}$ баб мендзи с̀уйет́у и фарзу гетӣ селеват́ спас̀енйе велќе пеи... (74a-77a);

20. Намаз в четыре рака'ата: баб поро̄ндек до̄ тих немаз́о̄в цุо по чтири реќе 'т́и абрекане то так треба мӯвии... (77a-77б);

21. Намаз во время поста: баб тойест хто у по̄сичи вахтӣ немаз́и йежели хиеш по̄з́ней о̄дмо̄длисе конечне фарз о̄дмо̄длицсе... (77б-79б);

22. Вирид ${ }^{8}$ : баб то йест по фарз̣е верит́ тоцисе велќе спас́ене пец... (796-84a);

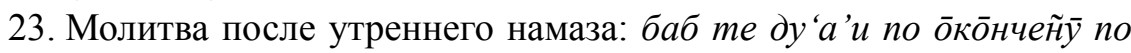
сабаху треба корнечне печ ренце по̄дйевши амйн...(84a-85a);

24. Зикр ${ }^{9}$ и молитва: а потим тетӣ з́икер по̄с̀ле а по̄тим ду 'a 'u пец... (856-89a);

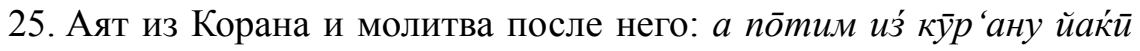
уммейеш айет́ пей по̄с̀ле айет́y тетӯ ду 'а пей... (89б-91б);

26. Зикр: то йест з́икер ймо̄на усих ано̄лов и проро̄ко̄в... (91б-93а);

27. Молитва никах хутба ${ }^{10}$ : баб ниќхх хутбет́ годзис́е те ду 'а'и ве малженс̀ќм с̀тане пеи... (93a-94б);

28. Молитва после каждого намаза: баб те ду' $a$ ’u по̄с̀ле каждего немаз́у тодзис̀ пеи... (946-95a);

29. Молитвы после полуденного, послеполуденного, вечернего

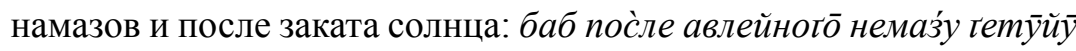
ду 'a'и треба пец..., то йест до аќиндейӯ ду' а будур..., то йест до ахиам немаз́у ду 'а будур пеи..., то йест до йет́иейӯ до немаз́у ду'а раземм до̄ вит́ир пец...(95а-98б);

5 Абдес (перс.) - малое омовение.

6 Гусл (ар.) - полное омовение.

7 Салават - молитва, прославляющая пророка Мухаммеда.

8 Вирид (тур. virt) - постоянное повторение молитв или стихов Корана.

9 Зикр - гимн, включающий многократное произнесение формул, содержащих в себе имя Аллаха или его имена-атрибуты.

10 Проповедь имама во время бракосочетания. 
30. Таравих ${ }^{11}$ намаз: баб то йест т́еревих немаз́ о̄дкланавщес̀е йет́ии немаз́... (98б-101б);

31. Кадыр намаз: то йежелй припа ? кадир немазे кадир немазे в половй ремазану хто хие то модлис́ по два реке 'атии... (101б-102а);

32. Тасбих ${ }^{12}$, аяты и молитвы: скорнчивщӣ т́еравйх и кадир немаз̀ [?] нехай пейе три рази кулгувеллагу албо гети т́ес̀пх... (1026-108б);

33. Молитва перед таравих намазом: баб та ду' $a$ 'и спотикайо̆ни т́еравих першего вечора йак ремизан настонпи... (108б-110б);

34. Молитва с джамиатом во время рамазана: баб то йест ве ремизан опо̄шнето т́еравйху кажди мус́улманин имусуллманка з джеме 'ат́ем велке спайене те ду 'а'и пеи... (111a-112б);

35. Нийет к посту рамазан: баб то йест абрекане до по̄сту ремезайет̄̄... (113a-113б);

36. Молитва после поста: баб то йест ӧдпо̄с́нико̄йоицс̀е те ду'а'и пей... (113б-114a);

37. Молитва во время новолуния: месо̄нща мло̄дето опачивщи те ду 'a'u пей... (114б-115a);

38. Байрам намаз: баб ведей поро̄ндек байрамнй... (115a-131a);

39. Хутба к Курбан байраму: баб то йест байрам курбан хутбе будур... (131а-135б);

40. баб над курбанем те ду 'а'и пеи треба... (135б-139б);

41. Проповедь перед никахом (бракосочетанием): баб порондек пред илуббем йак пред шлуббем зборо̄нсе то ӣмам те орацийо бенце читал... (139б-146б);

42. Молитвы при обряде побратимства: баб то йест до ахрет́ане те кторе собе назво̄нсе ахреияами... (146б-150a);

43. Святой Абдаллах видит во сне пророка: 'абдллейги с̀венти йедней ноци видзал през сен пророка йето мило̄с́... (150a-151a);

44. Пять иманов: пирши йман... (151a-153б);

45. Молитвы при пропущенных намазах: баб то йест хто немаз́ов некланесе то треба те ду'а пеи... (153б-154б);

46. Аят: а в тим айеце так то пише... (154б);

47. Молитвы раскаяния: баб йес́ли хто хие за трехи свойе чинищ покайанийев... (155a-158a);

11 Таравих - молитва, читаемая во время Рамазана после вечернего намаза, включающая 20 коленопреклонений.

12 Тасбих - воздавание хвалы Аллаху с произнесением формулы „Субхан Аллах” (слава Аллаху). 
48. Летоисчисление: баб то йест лиджба мес́о̄нщова поттреба ведзеи йак на кторим хуррфуу ро̄к стойи и йак но̄ в кторето дна випадайо̄... (158a-163б);

49. О благоприятных и неблагоприятных днях: баб о тош потреба ведзеи йак ктора тодзина на ио пануйе... (164a-167a);

50. Месяц Сафар ${ }^{13}$ : баб о сафару мес́отиу описӯие... (167a-168a);

51. Зикр: баб то йест йман з́икер будур каждй мусуллманин и мус́улманка ... то йест з́иќер будур то̄ тлуммачи... (168а-170а);

52. Молитва при облачении в новую одежду: баб нове одзейе укладайони на с́ебе тодзисе те ду 'а пеи... (170a-170б);

53. Толкование молитвы: тез́a шерех ${ }^{14} \partial y^{\prime} a^{\prime} u$... (170б-175б);

54. Молитва Нур ${ }^{15}$ : тез́а ду 'a' и нурр ал 'азฺим будур... (1756-181a);

55. Молитва Джамил ${ }^{16}:$ тез́a ду 'a'u будур джемйл... (181б-183б);

56. Молитва Каршийан: тез́ ду 'a 'и будур каршиййа велми спас̀онайа... (1836-185a);

57. Молитва Ин Дахале ${ }^{17}$ : тез́a ду 'a'u будур ин дехеле спас̀онейа ду 'a... (185a-186б);

58. Молитва Салават: тез́a ду 'a'u селеват́ будур... (186б-190б);

59. Молитва-оберег: баб хто те ду 'a' 'и пейе албо при со̄бе нос́й то пан бў

60. Молитва Хурф $\phi^{18}$ : тез́а ду 'a'u хурф будур... (190б-192a);

61. Молитва Салават: тез́а ду 'а'и селеват́ будур мухайед мустафа̄ селам аллейти... (192a-193a);

62. Аят-оберег: тетӣ айет́ пеи и при собе нос́ии велке спас́ене... (193a-194a).

Вторая исследуемая нами рукопись хранится на Восточном факультете Санкт-Петербургского государственного университета в коллекции Антона Мухлинского. Краткое описание коллекции А. Мухлинского находим в статье „Antoni Muchliński and his Collection of Arabic Manuscripts in the St. Petersburg University Library" [Deryagina, Frolova 1997: 45-51]. В коллекции А. Мухлинского, состоящей из 18 единиц хранения, четыре рукописи относятся к так называемым рукописям литовских татар. Это два тефсира (сигн. 867 и 868), полукитаб (сигн. 893) и интересующий

13 Сафар - 2-й месяц мусульманского лунного календаря.

14 Шарх - комментарий, толкование.

15 Нур - свет.

16 Джамил - красивый.

17 Ин Дахале (от ap. - dahale; тур. duhul, dahil) - вступление.

18 Хурф-буква. 
нас хамаил (сигн. 869). Хамаил (далее - ЛУ 869) состоит из $99+$ I листов размером $21,2 \times 17,8$ см. В рукописи не указана точная дата ее составления или переписки, но по имеющимся филиграням и надписям рукопись можно датировать первой половиной XIX в. - 1803 г. В каталог библиотеки Санкт-Петербургского университета рукопись включена как тефсир (сигн. і 868). В рукописи много текстов с интерлинеарным переводом, что могло привести к ошибочной каталогизации рукописи как тефсира, так как именно для последнего характерны интерлинеарные переводы. Впервые рукопись упомянута в работе Антона Антоновича „Белорусские тексты, писанные арабским письмом, и их графико-орфографическая система" [Антонович 1968: 103-109]. Полное палеографическое описание рукописи представлено в статье „Значение материалов проф. А. Мухлинского для развития татаристики в Литве. Коллекция арабографических славяноязычных рукописей Санкт-Петербургского университета" [Мишкинене 2016: 450-460].

Ниже предлагаем наше деление на темы с условными названиями и приведением инципитов (в скобках отмечены страницы хамаила):

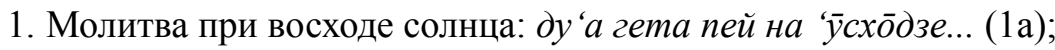

2. Молитва после утреннего намаза: па себаху пеu 'ōŭuy u матц̧е спас̀ейа пӧлецац... (2б);

3. Полуденный намаз и др.: авле немаз ду 'ас̀и будур..., ахшам немаз́ ду 'ас̀ будудр..., йет́си немаз́ ду 'ас̀и будуур... (3a-4a);

4. Нийет к таравиху: баб ниййет́ до т́еравиху кали сам имам бӯдеш..., два реќ 'т́и по̄кланивиис́е тен т́ес̀бих пет́... (5а-6а);

5. Кадыр намаз: два реќ 'ет́ кедир немаз́ кланейа 'а на кедир но̄ч дванас́це реќе 'ет́ев кланейа... (6б);

6. Таравих намаз: боже наш пане наш примй 'о̄д нас немаз́ наш немаз́ ḿеравих дла по̄велбейа месेо̄нцуа ремезана и дла по̄велбейа про̄ро̄ка мухейеда... (6б-10б);

7. О посте рамазан: борже пане палещайус́е йа табе с̀ветӯ 'увелбена ḿу ремезана мес̀еца дзис́ейшй дзен по̄сниковац твайо̄ прикезайе пелниц на мейсиу ставиц 'ад сабаху да ахшаму... (10б-11а);

8. Молитва на Курбан-байрам: ḿ ду 'а на курбан байрам над курбанам nеu.... (11б);

9. Молитвы при наречении имени: и бо̄же пане палецайус́е гетему дзицации визнавац йедииего̄ стварицуела бога иман пец то йест гетему мало̄му 'у вуши аззан пеи... (12a-13б);

10. Никах: бо̄же пане палецайус́е табе илӯб хутбе пеи за тего̄ сина або дачку... (13б-17a); 
11. Молитвы при обряде побратимства: ниййет́ ахретних бращи перепевайучи то йест ..., хто̄ хие ахретайа... (17б-18б);

12. Молитвы у постели больного: хоррего̄ навежкайучи гета ду' 'a'u пет́... (20a-20б);

13. Пять иманов: перши имман... (21б-22б);

14. Похоронный обряд: баб до мейит́a по̄ро̄ндек... (23a-42a);

15. Праздничный нийет: нийет́ до бейрам немаз́у то йест... (42a-55a);

16. Пятничный намаз (джума): до джум' 'а немаз́у... (55a-59a);

17. Сведения о мусульманском календаре: лиджба мес́онцо̄ва правдзива с турреикеке̄ виписана... (59б-60б);

18. О 24-х неблагоприятных днях в году: баб пан бу $\bar{\imath}$ му̀े $\bar{a}$ про̄ро̄ку приказал й мӯс̀а в ро̄ку двадзес́ие чтири днй него̄жих йест... (60б-64a);

19. Символ веры: про̄рокк мухайед рекл йешче до̄ пана бо̄та тойе чувши 'ано̄ли висьвечали... (64б-65a);

20. Перстень Давида: баб присланем 'о̄д пана бо̄та през джебра' ила 'ано̄ла до̄ крӯла давида 'але в тим персेцену вщелка мо̄ндрос́и

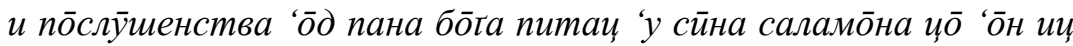
мо̄же 'о̄дповедзеи з мо̄ндро̄с́ии свойей... (65a-67a);

21. Молитвы на разные случаи жизни: те ду' 'а на 'абро̄к за здаро̄вйе чийо̆ 'абракайессе тедй нап̃̄̄й скаииней пец... (67a-72a);

22. Гадание по звону в ушах: то йест йак правейе уха заз́винии то̄ по̄вес́и каже йак кеторрего̄ часу кали 'а павуно̄чи... (72а1-72a6);

23. О десяти несчастьях в году: баб 'алӣ резийе ассегу ангу мо̄вил 'о̄д прорро̄ка йего мило̄́́ кезав иж 'у гаду дзесееи приго̄д йест... (72a7-7362);

24. Бевли ${ }^{19}$ намаз: то̄ йест бевле немаз́ пан бо̄т роззказав 'ад мо̄чи 'ад

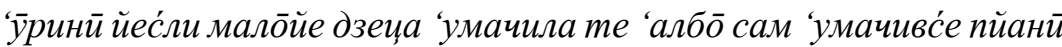
'умачивс́ тедй тего̄... (73б3-73б10);

25. О неблагоприятных днях: 'у недзелу шату кро̄йии него̄же фрасунек меи будзеш... (73б11-74а3);

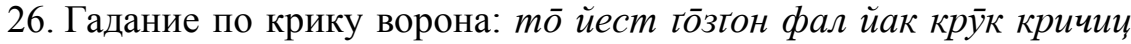

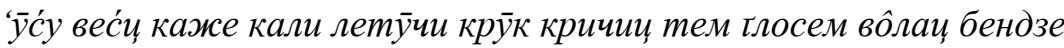
потим с́евши на з́емли... (74a4-76a5);

27. Зикр Хикмет: ай недужми адамс̀кий человек душа с цела вийдзе нихто̄ непажсалӯйе тилко̄ бо̄г... (76а5-79a1);

28. Зикр: борже наш дай нам тето четоि мй 'о̆д иебе жо̄ндамй през гети з̀иќер и в йавно̄с̀ии и в тайемно̄с̀џи... (79a1-86a6);

19 Бевли - моча. 
29. Чтение Корана: кур 'ан пей кур 'ан пей греховв 'адпуишчейе будзеш рано̄ и ввечер... (86a6-89a1);

30. Молитва Нур: дже 'ефер садик рехмету исе (?) 'али чӯв '’̄д про̄ро̄ке и кезав йа хезрет́ 'алий 'ад прорротке чув и кезав йа мухег̃ед прорро̄к йего̄ мило̄сии 'аднаго̄ дна у михраба с́едзев 'а тим час́ем джебра'ил алей алселам пришо̄в и селам дав мухепеед йего̄ мило̄с́ сेелам принав потим джебра 'ил 'а 'м каже... (89a1-95a2);

31. О пропущенных намазах: баб 'алий сेвентий мӯвил 'аднаго̄ дна зे прароќем зे меќейу да мединейу ишлй паткав 'арабин и мујвил да про̄ро̄ка ад шес́иидзес́ат го̄д майӯ засталейи немаз́и што̄ майе чинии... (95а2-95б2);

32. Молитва, известная шайтану: баб шейтан алей аллейгине давид проррокк мовил йа 'умейу 'адну ду'а'и перепевши будуу 'у райи не 'иначей... (96а1-96б10);

33. Тевбе: гета ду 'а 'и за грехи свайе кежнего̄ дна и часу за грехи т́евбе чини належи завще пей то̄ йест ду' ' 'и... (95б2-96а1);

34. Гороскоп: 'о̆знаймуйе кеторрего̂ дна диияа наро̄дзийа у йако̄м оббичайу майе бйи... (96б10-97б2);

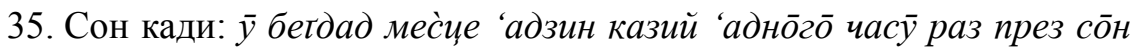
видзев мухейед про̄ро̄ке йего̄ мило̄с́и с тввари поввелбо̄ний зेменивс́е казий питав... (97б2-98а9);

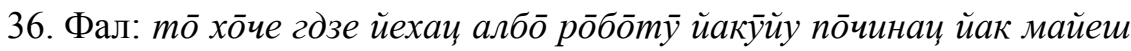
ведаи йес̀ли майе бйи до̄бра албо̄ зेле... (98а9-99).

Сравнивая расписанное содержание рукописей, можно заметить, что многие темы рукописи ХСК (середина ХІХ в.) и рукописи ЛУ_869 (первая половина XIX в.) близки между собой. Это, например, Таравих намаз (ХСК 98б-101б и ЛУ-869 5а-10б), Молитва на Курбан Байрам (ХСК 131а-135б и ЛУ-869 11б), Никах (ХСК 139б-146б и ЛУ-869 13б-17a), Молитвы при обряде побратимства (ХСК 146б-150а и ЛУ_869 17б-18б), Пять иманов (ХСК 151а-153б и ЛУ-869 21б-22б), Молитва Нур (ХСК 175б-181а и ЛУ-869 89а-95а). Только при текстологическом сопоставлении исследуемых текстов появится возможность установить, насколько тексты близки друг другу или же идентичны.

Некоторые наиболее популярные тексты из рукописей литовских татар уже ранее становились предметом текстологического исследования. Метод классической текстологии, предполагающий выявление различных списков одного и того же произведения с последующим сравнением их содержания и языкового выражения, ранее был применен автором статьи к некоторым текстам литовских татар, среди которых Диалог пророка 
Мухаммеда с шайтаном, легенда Мираджнаме, Погребальный обряд, О счастливых и несчастливых днях, Никах, шесть сказаний из китаба Ивана Луцкевича (первая половина XVIII в.) и Абрагама Карицкого (середина XIX в.) - О Марйам, О сотворении мира, О смерти Мухаммеда, О споре Мекки с Мединой, O сотворении разума, $O$ ворожбе. К анализу были привлечены тексты из известных и доступных автору рукописей. Список данных рукописей постоянно пополняется, поэтому на последующих этапах исследования к анализу предполагается привлечение и новых текстов. Установление отношений между исследованными списками в процессе текстологического анализа представляется актуальным на данной стадии китабистических изысканий, целью которых является установление локализации списков, гипотетических оригиналов, а также изменений на лингвистическом, культурном и историческом уровнях.

\section{3. Молитвы в рукописях литовских татар}

Намаз, или салат - каноническая молитва, одно из пяти обязательных предписаний ислама. Молитва первых мусульман состояла в совместном громком произнесении формул единобожия и возвеличения Аллаха. Порядок молений Кораном ясно не предписан, хотя есть многочисленные указания на такие детали, как время молитв, молитвенные формулы, некоторые движения и др. Считается, что весь порядок совершения молитвы сложился как подражание молитвенным позам и движениям пророк а Мухаммеда и закреплён памятью первых мусульман. Единообразие молитвы отрабатывалось практически в течение более чем полутора веков и было письменно зафиксировано ханафитским правоведом Мухаммадом аш-Шайбани (ум. в 805 г.) [подробнее см.: Ислам 1991: 204].

Основой намаза является рак'ат - цикл молитвенных поз и движений, сопровождаемых произнесением молитвенных формул, следующих друг за другом в строго определенном порядке. Число поклонов различно для каждой из пяти молитв (salat as-subh, salat az-zuhr, salat al- 'asr, salat al-magrib, salat al- 'aša).

Многовековая изоляция от мусульманского Востока, незнание собственного литургического языка (арабского) и христианское окружение затрудняли глубокое и полноценное знание литовскими татарами их собственного исламского вероучения, однако, тем не менее, местная традиция сохранила основные, наиболее важные религиозные положения и понятия. Надо сказать, что „татары принесли с собой (в Великое княжество Литовское - Г.М) ислам суннитского направления, включавший в себя остатки древних верований тюркских кочевых 
племен” [Borawski, Dubiński 1986: 187], и это засвидетельствовано историческими источниками, в частности, письмом турецкого султана Мурада III к польскому королю Сигизмунду III от 1591 года [Tyszkiewicz 1987: 91]. Литовские татары придерживались этого направления в течение всей своей истории на новой родине.

Зародившаяся в середине XVI в. арабографическая славяноязычная письменность литовских татар во многом способствовала сохранению религии и культуры у литовских татар и позволила им избежать полной ассимиляции. Рукописная книга в культуре литовских татар занимает особое место, так как именно традиционная письменность несла в себе историческую память, поддерживала традиции и обычаи в мусульманских семьях. На протяжении веков она оставалась и единственным источником религиозной культуры мусульман ВКЛ.

Литературное творчество литовских татар, будучи герметичным по своему характеру, предназначенным для удовлетворения внутренних потребностей небольшой общины, в течение XVI-XX вв. всего несколько раз заявило о себе во всеуслышание. К наиболее известным произведениям относится „Апология” Азюлевича [1630] и работа И. Соболевского „Изложение веры магометанской или исламской” [Sobolewski 1930]. „Апология” Азюлевича стала ответом на антитатарский и антиисламский пасквиль П. Чижевского „Альфуркан татарский” [1616]. Цитаты из „Апологии” находим у И. Крашевского, однако само произведение на сегодняшний день считается утерянным. И. Соболевский, заседатель нижнего земского суда, в своей книге изложил на польском языке основные догматы ислама, чтобы они стали понятными всем мусульманам. Во введении И. Соболевский [1830, IV] отметил, что за основу в работе брал многие главы Корана и хадисы, таким образом, именно у И. Соболевского впервые косвенно упоминается о письменности литовских татар. Непосредственно в трактате И. Соболевского в разделе „О modlitwie” поясняется предназначение молитв и порядок молений: „О jak wspanialą jest rzeczą myśleć o Bogu, co w naszych czynimy modlitwach, mówi Bóg w Piśmie świętem: Nie zaniedbujcie modlitwy! Ona odpędza wszelkie występki, i wszystko co tylko jest niegodziwego. Módlcie się bez przestanku" [Sobolewski 1830: 48]. Раздел „О modlitwie” находится на страницах 48-79 указанного трактата. Среди описанных порядков моления встречаем и моления во время поста Рамадан - Таравих ${ }^{20}$ [там же: 70-72].

20 Таравих - молитва, читаемая во время Рамазана после вечернего намаза, включающая 20 коленопреклонений. 


\section{4. Молитва Таравих в исследуемых рукописях}

Таравих - желательная молитва, Сунна и за несовершение ее не полагается наказания. Эта молитва ничем не отличается от дополнительных молитв в другие месяцы. В предписаниях о совершении молитвы Таравих читаем следующее:

1. Намерение в сердце совершить 2 ракаата молитвы Таравих ради Аллаха.

2. Совершение молитвы из двух ракаатов. В каждом ракаате читается аль-Фатиха и, желательно, какой-нибудь отрывок из Корана (будь то один аят, несколько аятов, целая сура или несколько сур). Согласно Сунне, первый ракаат должен быть длинее или, по крайней мере, не короче второго ракаата.

3. После таслима („Салам” в обе стороны для завершения намаза), можно встать на следующие 2 ракаата и повторить условия пункта 1 и 2.

4. Повторить так (т. е. по 2 ракаата) 4 раза, чтобы получилось 8 ракаатов, а потом сделать 3 ракаата намаза уитр с соответствующим намерением. ... витр не должен походить на намаз магриб, поэтому после второго ракаата не читается ташаххуд, а сразу поднимаются на третий ракаат, в конце которого читается все, как обычно для последнего ракаата [(Ислам. Помощь в исламе)].

В работе И. Соболевского находим следующие указание о способе совершения молитвы Таравих: „... po skończeniu 10ciu pokłonów modlitwy Jetcy przed modlitwa Witri czyni się postanowienie (Nijet) do Terawichu, którego 4 pokłony odprawiwszy, śpiewa się 112 Rozdział z Koranu po 3 razy, i to powtarza się tymże sposobem, aż się nie naliczy 20 pokłonów. Po czem następne odmawiają się wyrazy... . Po skończeniu tego, wyżej rzeczonym sposobem odprawuje się Witri i kończy się to nabożeństwo jak wszystkie inne na odśpiewaniu Ajetiul-Kursi" [Sobolewski 1830: 70-71].

В рукописи ХСК Таравих намаз находится на страницах 98б-101б. Фрагменты арабографичного текста Таравих намаза транслитерированы кириллицей по системе транслитерации, разработанной Антоном Антоновичем [Антонович 1968: 192-194].

Транслитерированный текст Таравих намаза:

986 баб то йест т́еревих немаз̀ о̄дкланавщес́е йет́ии 99а немаз то потим двацаи реќ 'ат́ов т́еравиху кланацисе за имамем абрекаис́ п потим т́еравих оддорливщисе то витри ваджиб три реќе 'ат́и 
кланаисе то йест абжекане до т́еравихй $\bar{y}^{21}$ [тур.-пол.] и бо̄же пане полецамс́е тобе

двадзес́це реќе‘ат́̄̄ т́еравих немаз̀ клацис́е и с дзес́енцма с̀еламами у̀ тих четиро̄х реќе'ат́ах т́ес̄бих пец и пане йам йест ймам над меншчинами и белогло̄вами

кторе за мно полецайо̄нсе мам вистарчиц тен тваро̄м до̄ ќе‘абейӯ ӯклон сेеджде мо̄йе правдзивемӯ бо̄гу

$99 б$ услўга мо̄йа йединемеу бо̄гӯ иде за кур'анем шчере и шчирим сердзем бо̄гу̀ висоќемӯ

аллагу аќбар с̀убхани пей в першим реќе 'ат́у пеи раз алхемду и тен айет́ пей [ар.-пол.] и завс́е бо̄йцес́е бўга изали бендзеце во̄лнеми о̄д вшистќего в друййм

реќ 'ат́'̄ раз алхемду и тен айет́ пей кендй майӯ по̄вврӯдзис по̄врӯцо̄нс́е назад два реќ 'ат́ поклоницс́е житло̄ лӯдзќе пей и по̄сле бо̄жй с̀елам дай и тен ḿес̀бих айет́ пей и грӯнтуунц и направайо̄нц нунтро̄с́ц лӯдзќе и о̄с́веч о̄чй лўдзќе и ство̄рицелў

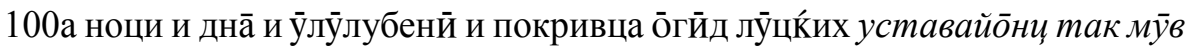
усставайце до теревихӯ и поцииху селеват́ перепей и боже наш з̀милуйсе над панем нашим мухейедем и над до̄мо̄вство̄м мухемедовим и ренц̧ам до $\bar{y} х \bar{в} в$ велќемй

палцамй доткнцсе мӯвиц и боже велќй а потим у трецим

реќ 'aḿȳ раз алхамду и хвала $u$ тен айет́ пей и мухем̃ед виглондай не на згуба йх о̄не певне виглондайо не на згуба тво̄йа

a y чвартом реќe 'aḿe раз алхемду и хвала и тен айет́ пей прето мухем̃ед виглондай не на згӯба

$100 б$ бо о̄ни ца певне на тво̄йо згуба апатрӯйо̄ с̀елам давщй и тен т́ес̀бих пей чистй исто̄тнй

кру[л] над крууламй и ӯ сво̄йим крӯлевстве чистй боже годнй и повагй и велќй ӯ велко̄с́ци и строгй страшнй

и мо̄цнй пз̀цивкӯ пишних и над гардеми гарди и велќй над велќеми и пенкнй над пенкнеми и мо̄цар над мо̄царамй чистй

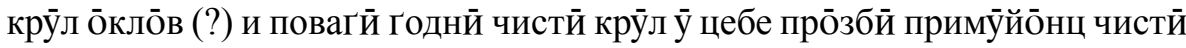
крўл вшистќих ро̄дзайо̄в успоро̄нцоних

чистй крўл правдзивй бууг живй и жийо̄нци лехкосерднй кторй не спй и не йе и не с́мертелнй и

21 Записанные красными чернилами фрагменты текста оригинала помечены курсивом в транслитерированном тексте. 
не минайо̄нци и не с́венцони вечнй хвалемй цебе с́вентего и чистего пана нашего и пана 'анелс́ќего и вшистќих дӯхо̄в

101а чтери рази до потти пей а̃ понтие те ду 'a'и аж до ко̄нща пей

[ар.-пол.] и ласкавй о̄дпуускливи и през́б вдзенчнй и шчодро̄бливй и до̄бро̄дливй уттворцца внентро̄с́ци и вари

правдзивей и о̄д цебе о̄дпо̄нчена грехов о̄дпӯскливй и мухемеед и ӱвелбонй причинайс́е за нами дна̄ со̄нд[не]го

при шалех не маш иншего бога тилко бўг аллах мухем̃ед посл божй не маш иншего бога тилко буг аллах мухемеед

прийацел божи не маш иншего бўга тилко бўг аллах мухем̃ед причинца до̄ бугга и хвалеми цебе с́вентего чистего пана нашего

и пана 'анелс́ќего и вшистќих дӯхо̄в и пане наш вереми тобе нам и цо зеслал ксеенга кур'ан идземе за но и за проро̄ками и по̄сламй 1016 прето абис́ нас прйвоิл вспӯл с́ва̄дчо̄нцеми в йедино̄ство̄ свойе таќим поро̄ндќем по чтери реќе 'ат́и

$101 б$ увес́ т́еравйх поврстат́и? то с̀елам дай зко̄нчившй т́еравйх йежелй припа кадир немазे кадир немаз̀ в половй ремазану хто хие то модлисе по два реќе 'ат́и...; 1026 ско̄нчившӣ т́еравйх и кадир немаз̀ [?] нехай пейе три рази кулгувеллагу албо гети т́ес̀их...;

$108 б$ баб та ду 'а'и спотикайо̄ни т́еравих першето вечора йак ремизан настонпи... .

В хамаиле ЛУ_-869 тексты, касающиеся Таравих намаза, находятся на страницах 5a-10б рукописи.

Транслитерированный текст Таравих намаза:

5а баб ниййет́ до т́еравйху кали сам имам бӯдем

[тур.-бел.] боже пане палецацс́е двацац

реќе“ат́̄в теравйх немаз̀ кланец̃а з̀ дзес̀ецма с̀еламеми 'у чатиро̄ реќе‘ат́а медини? т́есбих пец и пане йа йестем имамо̄м

мушчинам и белиглоิва ктӯре за мно̄ по̄лецайо̄нс́е майо̄ вистарчиц тварем да ќе‘бейу 'укло̄н мо̄йе панӯ бо̄гу услӯга

йемӯ йедин̃омӯ бо̄гу иду за кур“анем шчере правдзиве бо̄гу висо̄кему два реќе 'ат́и по̄кланившис́ тен т́ес̀бих пет́

[ар.-бел.] и грӯнтӯйо̄нци направуйо̄нци нутр чло̄вечи и 'о̄с̀вецайо̄нци о̄чи члоิвече ствоिрицелу но̄ци и дна велебнй по̄кривце 'о̄гиди

$5 б$ чтери реќе 'ат́и по̄кланивщис́ тен т́ес̀бих пей

[ар.-бел.] чистй хвалебни крул в своิйим крӯлевстве чисти бо̄же го̄дни по̄ваги и велко̄с́ци велќй сро̄гй страшни мо̄цни прецивку пишнего̄ пишни 
над гардими гарди велќй харо̄ши чисти крӯл 'о̄д цебе про̄з̀ба ‘о̄тримана чисти бо̄же крӯл 'ӯкло̄но̄в и по̄слӯґ го̄дни чисти крӯл

вшистќих ро̄дзайоิв и ство̂рен̃е чисти крӯл живи лехко̄сердни ктӯри не с̀пи и не с̀мертелни и не майо̄нци и не ско̄нчо̄ни вечни 'уставичнй хвалеми хвалеми цебе с̀вентего̂ чистего̂ пана нашего̂ и пана 'анелс̀ќего̂ вшитќих дуухо̄в спелна двацац реќе 'ет́ев 'о̄дкланевшис́е пет́

[ар.-бел.] и ласкави и 'о̄дпӯскливи и про̄з̀би ведзенчнй и шчо̄дро̄бливй до̄бро̄кливй 'ӯдтвоิрца не тримӯй верӯ йманем спо̄дзева мне 'о̄дпӯшчейе грехоิв мо̄йих

6а и мухейед и 'увелбо̄ни причинца за нами дна со̄нднего̂ при шалах наших не маш иншегоิ бо̄га тилко̄ бӯг аллаг мухем̃ед про̄ро̄к по̄со̄л бо̄жи не маш иншегоิ бо̄га тилко̄ бӯг прийацел

бо̄жи не маш бо̄ге тилко̄ бӯг мухемед причинца до̄ бо̄ґе хвалеми цебе чистего̂ с̀вентего̂ пана нашего̂ и пана 'анелс̀ќего̂ и вшитќих дӯхо̄в пане наш верам то̄бе цо̄ зеслалес́ ксенне своิйа идземи за про̄ро̄ками твоิйими и пши нас сेвадцо̄нцеми в йедино̄̄ствӯ

ќедир немаз̀ два реќ“ет́и ќедир немаз̀ кланец̃а ќедир но̄ч дванас̀це реќ‘ет́ев кланеца

‘а до̄ кедиру и по̄ кедиру по̄ два реќ‘ет́и кланец̃а а в тих реќ‘ет́ах по разу

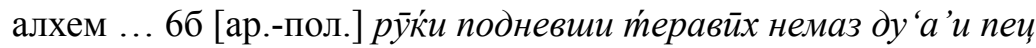

бо̄же наш пане наш прийми 'о̄д нас немаз̀ наш немаз̀ т́равйх дла по̄велбениа месेонца ремезана и дла по̄велбен̃е

про̄ро̄ка мухем̃еда 'о̄статнегоิ и дла правдзивоิс̀ци т́еврйт́у инджйлу аванелийи и псалтира грецќего̄ и кур‘анӯ и дай нам риз̀ку

в тим мес́о̄нцу и спор и о̄дпус́чейе грехоิв и визвоิл нас 'о̄д 'о̄гна и 'о̄д менќи пеќелней и 'о̄д воิди го̂ро̄нцей и 'о̄д дзегцу смо̄лй ќипо̄нцей

‘'̄чин воิлними нас при вадзе ти йест мило̄сердни над мило̄сердними дла по̄велбен̈а и ласкави висо̄ќи про̄з̀би вдзенчнй

шченс́ливи бо дай пришедлес́ и мес́о̄нцу ремезане 'у мило̄сердзне й мило̄сердни над мило̄серднеми и хвала бо̄гу панӯ вшитќих с̀вато̄в 7а баб йак 'о̄дпо̄с̀никӯйес̀се перши кӯс 'укӯс̀ивши пей..., першега вечера теравйх гети пей [тур.-бел]...;

9a ‘апошнаго̄ вечера прешшчайӯчис́е ремезанӯ гета пей... .

В данной работе мы не ставили цели проведения полного текстологического анализа выбранных фрагментов текстов. Для нас было важно показать, что даже при первом знакомстве с текстами Таравих намаза, входящими в тематический блок, условно названный О посте рамазан, и их сравнении обнаруживается не только вариативность самого текста и его языкового 
выражения на всех лингвистических уровнях, но и отличительные черты орфографии и структуры. Показав на небольшом примере значимость описываемых фрагментов рукописей и не вдаваясь в подробный языковой анализ приводимых отрывков, обратимся к проблеме славяно-турецкого языкового и культурного взаимодействия.

\section{5. Славяно-турецкое языковое и культурное взаимодействие}

Как уже отмечалось, языковая ассимиляция литовских татар сделала необходимой перевод на белорусский, а затем и польский языки религиозной литературы - сур и отдельных аятов Корана, непонятных литовским татарам арабских текстов молитв, легенд о пророке Мухаммеде, текстов, связанных с ритуальной обрядовостью мусульман ВКЛ.

Редкими, но тем не менее очень значительными для исследователя являются встречающиеся в рукописях литовских татар двуязычные тексты - арабо- и тюркоязычные с подстрочным переводом на славянские языки - (старо)белорусский и (старо)польский. Опираясь на исследования рукописного наследия литовских татар, можем говорить о процессах их языковой ассимиляции, связанной и с процессами переселения на территорию ВКЛ. На первом этапе (XIV-XV вв.) большая часть мигрантов принадлежала к кыпчакской языковой группе еще до ее диалектного членения в начале XV в. и выделения крымскотатарского диалекта. Второй этап (XVI-XVII вв.) следует связывать с поселенцами, находящимися под османо-турецким языковым влиянием. В научной литературе упоминаются четыре восточных языка, которые зафиксированы в рукописях мусульман ВКЛ: хорезмийский, чагатайский, староосманский и крымско-татарский языки. Ананьяш Зайончковкий в своей статье приводит пример текста на хорезмско-тюркском языке (у А. Зайончковского - староуйгурский) из хамаила (1804), хранящегося в Институте восточных языков Варшавского университета (сигнатура: Instytut Orientalistyczny U. W. Rękopisy 1) [Zajączkowski 1951: 308-313]. Начатое А. Зайончковским и Т. Майдой исследование тюркских и арабских текстов, продолжено Н. Гюллюдаг, А. Дроздом, Х. Дургутом, Г. Мишкинене, П. Сутером, Г. Янковским [Güllüdağ, Miškinienè 2008; Drozd 1999; Дургут, Мишкинене 2009: 357-375; Durgut 2016; Suter 2004; Jankowski 1995]. В 2016 г. вышла статья Магды Левицкой, посвященная одной из жанровых разновидностей рукописного наследия литовских татар - грамотке из собрания Исторического музея г. Белосток (Польша) [Lewicka 2016: 69-90]. Автор статьи анализирует арабоязычный текст грамотки и предлагает его перевод на современный польский язык. 
В том случае, если текст в рукописи не двуязычен, установить его первоисточник, с которого делался перевод - арабский или тюркский бывает затруднительно. Достаточно часто в самом тексте можем найти указание на источник: „как в Духан-суре Господь Бог сказал”; „как в Коране записано”; „как Господь Бог в суре ар-Рахман пишет”. Основным источником арабских вставок служил Коран, определенные суры которого (например, сура Ал-Хамд) могут быть процитированы целиком несколько раз, в иных случаях приводятся лишь их фрагменты. Другим источником цитирования служили хадисы - предания об изречениях и деяниях Мухаммеда. Установить, откуда именно взяты эти хадисы, довольно сложно. Среди источников следует отметить и различные мусульманские книги о деяниях пророков, сборники молитв. Так, например, в китабах можно встретить такие указания на конкретные источники: у китабе кензеде значи; у мешарику китабе пише; баб у китабе шуруту селоту пише; баб у китабе кузуде пише; у фетвайу пише и т. п. Тексты непосредственно брались и из турецких источников, например, как в случае с текстом „О благоприятных и неблагоприятных днях”, который взят из китаба Абду-л Канийа'22: баб то йест с туррецүкаго ќй́абу 'абду алканийа имама на полс̀кий йезฺк виложона аби луудзи посполити виразуумели йак йест дни добре йак недобре... . В хамаиле ЛУ-869 во фрагменте текста, условно названном Сведения о мусульманском календаре, читаем: лиджба мес́о̄нц̧о̄ва правдзива с тӯрец̧ќет̄̄ виписана... (59б-60б). При установлении источника проповеди перед венчанием (хутбы перед никахом) выясняется, что он мог быть как непосредственно арабо-тюркский, так и славянский (польский) [Drozd 1999: 26]. Версии об использовании того или иного источника могут быть самыми разнообразными как в силу недостаточной изученности материала, так и по причине огромного количества мусульманских книг со сходными названиями.

Много интересного об источнике можно почерпнуть из анализа значительного пласта арабо- и тюркскоязычной лексики, сохранившегося в текстах письменных памятников мусульман ВКЛ. При переводе c арабского или турецкого языков религиозная терминология, общеизвестные (сохранившиеся) слова и выражения не просто калькировались, но и адаптировались, облекаясь в фонетическую и морфологическую оболочку белорусского и польского языков. Обычно без каких-либо фонетических и морфологических изменений и без перевода на вышеупомянутые славянские языки даны строчки из молитв

22 Абду-ль-Гани ан Наблуси (1641-1731) - выдающийся мусульманский ученый, суфий. 
и некоторые религиозные термины. Такое написание предполагает хорошее их знание верующими мусульманами. Часто встречаются следующие арабо- и тюркоязычные лексемы: айат, абдес, ахшам, вирид, витр, гаргара, гусл, давур, джахил, дуаи, дуасы, зирец, иман, искат намаз, йетци, кибла, мейит, нийет, сабах, саван, сарик, сурет, табут, тегрет, товбе, умур намаз, фалан ибн фалан, фарз, фута, харам и т. п.

Наличие в рукописях двуязычных текстов дает исследователю обширный материал, позволяющий проследить изменения, происходящие в тексте в области лексики, фонетики, грамматики и орфографии, оценить качество перевода, более точно установить источник текста.

Что касается текста Таравих намаза в исследуемых нами рукописях ХСК и ЛУ-869, можно предполагать, что он взят из турецкого источника, так как намерение (нийет) совершать Таравих намаз записано на староосманском языке с переводом на белорусский и польский языки.

Во время исполнения Таравих намаза могут читаться разные молитвы. Даже на примере двух хамаилов мы видим, что набор молитв не совсем идентичен. Интересно совпадение формально-содержательного смысла одной молитвы ${ }^{23}$, приведенной в трактате Соболевского и в хамаиле ЛУ-869.

В работе Соболевского читаем: „Jeszcze po tej modlitwie należy te wyrazy odmawiać: w Imie litościwego i miłosierniego Boga. Boże nasz, przyjm od nas modlitwę Terawich, dla uświetnienia xiężyca Ramazanu, i dla uczczenia Proroka Machometa ostatniego ze wszystkich Proroków, i dla sprawiedliwości xiąg świętych. Daj nam Panie, pożytki przez ten święty miesiąc, odpuść nam grzechy, uwolnij od mąk piekielnych i wesprzyj przy wadze w przyszedłem życiu, nakoniec witaj nam xiężycu Ramazan! i niech będzie na zawsze chwała Bogu władzcy światów" [Sobolewski 1830: 71-72].

В хамаиле ЛУ-869 на странице $6 б$ находится арабский текст молитвы с переводом на польский язык: „бо̄же наш пане наш прийми 'о̄д нас немаз̀ наш немаз̀ теравйх дла по̄велбейа мес̀онца ремезана и дла по̄велбейе про̄ро̄ка мухеи̃еда 'о̄статнегоิ и дла правдзивоิс̀ци теврйт́у инджӣлу аванелийи и псалтира грецќего̄ и кур`анӯ и дай нам риз̀ку в тим мес́о̄нцу и спор и о̄дпус́чейе грехоิв и визвоิл нас 'о̄д 'о̄гна и 'о̄д менќи пеќелней и 'о̄д воิди гоิро̄нцей и 'о̄д дзегцу смо̄лй ќипо̄нцей 'ӯчин воิлними нас при вадзе ти йест мило̄сердни над мило̄сердними дла по̄велбейа и ласкави висо̄ќи про̄з̀би вдзенчнй шченс́ливи бо дай пришедлес́ и мес́о̄нцу ремезане 'у мило̄сердзне й мило̄сердни над мило̄серднеми и хвала бо̄гу панӯ вшитќих с̀вато̄в”.

23 У Соболевского читаемые после 20 поклонов молитвы назваются Wyrazami. 
Сравнение данных фрагментов подтверждает гипотезу проф. Чеслава Лапича о том, что, несмотря на заявление Соболевского об использовании при работе над трактатом текстов из китабов, хамаилов и тефсиров, он их не цитирует [Łapicz 2013: 197-200]. Можно предположить, что Соболевский неплохо знал исламскую литургию или же прибегал к помощи знатоков ислама из среды литовских татар. Дальнейшие исследования переведенных молитв литовских татар помогут опровергнуть или подтвердить данное предположение.

\section{6. Заключение}

Обращаясь к сохранившемуся литературному наследию литовских татар, следует иметь в виду, что мы имеем дело с многоязычными памятниками, дающими богатый материал для исследований белорусского, польского, арабского и тюркского языков. Поэтому по-прежнему актуальной остается расшифровка всего памятника, а не отдельных частей, будь то славяноязычных или арабо- и тюркоязычных.

Кроме того, большое количество ритуальных молитв, переведенных с арабского или староосманского языков, является прекрасным сопоставительным материалом, позволяющим исследователю судить о возможных источниках, качестве перевода с языка оригинала и, конечно, об уникальном синтезе культур.

\section{Библиография}

Антонович Антон (1968), Белорусские тексты, писанные арабским письмом, и их графико-орфографическая система, Вильнюс.

Borawski Piotr, Dubiński Aleksander (1986), Tatarzy polscy. Dzieje, obrzędy, legendy, tradycje, Warszawa.

Güllüdağ Nesrin, Miškinienė Galina (2008), Litvanya Tatarlarına ait el yazmalarından Türkçe-Lehçe kılavuz (yıl 1840), Lietuvių kalbos institutas, Vilnius.

Deryagina Tamara, Frolova Olga (1997), Antoni Muchlinski and his Collection of Arabic Manuscripts in the St. Petersburg University Library, „Manuscripta Orientalia", Vol. 3, No. 4, p. 45-51.

Drozd Andrzej (1999), Arabskie teksty liturgiczne w przekładzie na język polski XVII wieku, Dialog, Warszawa.

Durgut Hüseyin (2016), İbn Abraham Karitski Kitabı Miraçnamesi. İnceleme-MetinDizin, Kömen Yayınları. 
Дургут Хусеин, Мишкинене Галина (2009), Легенда Мирадж из китаба Ивана Луцикевича, w: Lietuvos Didžiosios Kunigaikštystès kalbos, kultūros ir raštijos tradicijos: [straipsniu rinkinys], 357-375, Lietuvių kalbos institutas, Vilnius.

Ислам. Энциклопедический словарь (1991), Москва.

Ислам. Помощь в исламе, http://www.helpinislam.com/kak-sovershat-molitvuteravix-v-ramazan-ramadan/ [online 26.05.2017].

Jankowski Henryk (1995), A Polish-Tatar Ziker, „Acta Orientalia Academiae Scientiarum Hung", t. XLVIII, p. 405-420.

Клепиков С.А. (1959), Филиграни и штемпели на бумаге русского и иностранного производства XVII-XX вв., Москва, с. 108, № 186 - 1844 г.

Kulwicka-Kamińska Joanna, Łapicz Czesław, red. (2015), Tefsir Tatarów Wielkiego Księstwa Litewskiego. Teoria i praktyka badawcza, интернет ресурc: http://www. tefsir.umk.pl/pliki/Tefsir_Tatarow_WKL.pdf [dostęp: 15.06.2017].

Lewicka Magdalena (2016), Dualary planetne. Hramotka ze zbiorów Muzeum Historycznego w Biatymstoku. Analiza tekstologiczno-filologiczna, „Literaria Copernicana", 2 (18).

Łapicz Czesław (2013), Źródła cytatów koranicznych $w$ „Wykładzie wiary mahometańskiej czyli islamskiej..." Józefa Sobolewskiego z 1830 r., w: Tatarzy Wielkiego Księstwa Litewskiego w historii, języku i kulturze, red. Joanna Kulwicka-Kamińska, Czesław Łapicz, Towarzystwo Naukowe, Torun, s. 185-202.

Мишкинене Галина (2007), По следам Казанского китаба КУ-1446, „Senoji lietuvių literatūra", 24. Vilnius, p. 263-285.

Мишкинене Галина (2015), Арабографичные рукописи литовских татар в контексте культурных взаимосвязей: коллекиии Казанского (Приволжского) федерального университета и Наииональной библиотеки Республики Tamapcmau, w: Kintančios Lietuvos visuomenè: struktüros, veikejjai, idejos, sud. Olga Mastianica, Virgilijus Pugačiauskas, Vilma Žaltauskaite, Vilnius: LII leidykla, p. $42-59$.

Мишкинене Галина (2016), Значение материалов проф. А. Мухлинского для развитиятатаристикив Литве. Коллекция арабографическихславяноязычных рукописей Санкт-Петербургского университета, w: Актуальные вопросы тюркологических исследований. К 180-летию кафедры тюркской филологии Санкт-Петербургского государственного университета. Сб. статей под ред. Н.Н. Телицина, Й.Н. Шена - Спб.: СПбГУ, с. 450-460.

Sobolewski Jozef(1830), Wyklad wiary mahometańskiej czyli iślamskiej wyjęty z części Kóranu i przykazań praroka chadisiem zwanych, Wilno.

Suter Paul (2004), Alfurkan Tatarski: Der litauisch-tatarische Koran-Tefsir, Köln.

Tyszkiewicz Jan (1987), Pismo sultana Murada III z roka 1591 w sprawie Tatarów litewskich, „Studia Źródłoznawcze”, t. 30, s. 75-97. 
Тарэлка Міхаіл (2011), Рукапісы татараў Беларусі канцуа XVII-пачатку XX cm. з дзяржайных кнігазбораў краіны. Каталог, Складальнікі: М.У. Тарэлка, А. І. Цітавец, Мінск.

Zajączkowski Ananjasz (1951), Tzw. chamait tatarski ze zbiorów rękopisów $w$ Warszawie, „Sprawozdanie PAU”, t. 52, nr 4, s. 308-313.

Galina Miškinienè

Slavic-Turkish Linguistic and Cultural Interaction on the Material of Lithuanian Tatar's Chamails

One of the most common genre varieties of literary heritage of Lithuanian Tatars is the chamails. Due to their content, chamails are divided into two groups: prayer's, intended for imams, and so-called faldjey's, which besides prayers and descriptions of rituals includes materials on the Muslim chronology, advices on the treatment of diseases with the help of prayers, interpretation of dreams, magic texts. Unbelievable value for researchers represents chamails, in which most of the eastern texts of ritual content and prayers are accompanied by an interlinear translation into Belarusian / Polish language.

The translated texts from the manuscript (signature 3246 ar.), stored at the Manuscripts and Rare Book Department of the Scientific Library of Kazan Federal University, and manuscripts (signature No. 869) from the collection of professor A. Muhlinsky, stored at the Library of St. Petersburg University, is going to be the object of the comparative study.

KEYwords: Lithuanian Tatars; manuscripts; chamail; Slavic; Turkish; Culture.

dr Galina Miškinienė - docent w ośrodku badań nad językiem tureckim Uniwersytetu Wileńskiego, pracownik naukowy w Instytucie Języka Litewskiego w Wilnie, tłumacz; zainteresowania naukowe: rękopisy i dziedzictwo kulturowe Tatarów litewskich i polskich, związki kulturowe Litwy i Turcji, islam na terytorium Wielkiego Księstwa Litewskiego. 
